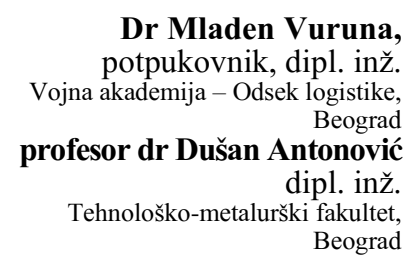

Dr Mladen Vuruna, Vojna akademija - Odsek logistike Beograd

dipl. inž

Beograd

\section{MIGRACIJA DIZEL GORIVA IZLIVENOG U POVRŠINSKE SLOJEVE ZEMLJIŠTA}

UDC: $665.75: 504.5$

Rezime:

U radu su prikazane osnovne fizičko-hemijske karakteristike dizel goriva i zemljišta. Objašnjena je migracija izlivenog naftnog zagađivača kroz vertikalni profil zemljišta. U eksperimentalnom delu ispitivane su koncentracije dizel goriva i relativne koncentracije $n$-alkana u površinskim slojevima peska, u koje gorivo dospeva kao posledica akcidentnog izlivanja. Utvrdeno je da se koncentracije dizel goriva menjaju sa vremenom nakon izlivanja u svim ispitivanim slojevima. Takode, utvrdeno je da se dizel gorivo, kao potencijalni zagadivač, u prvih šest nedelja, uglavnom, zadržava u površinskom sloju dubine $30 \mathrm{~cm}$, a objašnjene su i mogućnosti sanacije zagađenog zemljišta.

Ključne reči: dizel gorivo, zemljište, koncentracija izlivenog goriva, relativne koncentracije n-alkana, tehnike čišćenja.

\title{
MIGRATION OF DIESEL FUEL SPILLED IN SUBSURFACE LAYERS OF SOIL
}

Summary:

The basic physical and chemical properties of both diesel fuel and soil have been given in this article and oil pollutants migration through vertical soil profile have been explained as well. In the experimental part of the paper both the concentrations of diesel fuel and relative concentrations of $n$-alkynes spilled in sandy soil by accident have been investigated. It has been proven that the concentrations of diesel fuel have changed in all layers of soil depending on the time after spill. Diesel fuel as possible pollutant has been retained $30 \mathrm{~cm}$ deep in sandy soil during six weeks after spill. Finally, cleanup techniques of polluted soil have been explained.

Key words: diesel fuel, soil, spilled fuel concentration, $n$-alkanes relative concentratiions, cleanup techniques.

\section{Uvod}

Na početku 21. veka nafta kao strateška sirovina i osnovni energetski resurs, postaje sve značajnija. Sa narastajućim značajem nafte tesno su povezana i dva problema: problem rezervi i zagađenja životne sredine. Ovaj drugi problem je poslednjih decenija obeleženih vrtoglavim tehnološkim napretkom, dospeo u samu žižu interesovanja javnosti ekonomski razvijenih zemalja. U razvijenom svetu gotovo da nema institucija koje ne pridaju poseban značaj zaštiti životne sredine i u svoje planske aktivnosti uključuju preventivne mere i postupke zaštite. Tako je, na primer, obaveza svih građana i institucija na Floridi da nadležnim državnim organima prijave izlivanja goriva koja su veća od 25 galona (95 litara) [1]. Ipak, uz sve napore, životna sredina je i dalje ugrožena, svakim danom sve više. 
Nafta i njeni derivati, uz pesticide, predstavljaju osnovne zagađivače tri aspekta životne okoline: vode, vazduha i zemljišta. Problem zagađenja naftom i njenim derivatima je složen, jer je reč o smešama čiji uticaj na životnu sredinu zavisi od fizičko-hemijskih karakteristika jedinjenja koja ulaze u njihov sastav, osobina same smeše, kao i uslova i stanja u životnoj sredini. Zbog toga je praćenje promena na takvom zagađivaču, što je važan korak u donošenju odluka koje se tiču zaštite ili saniranja posledica zagađenja, veoma složena aktivnost na koju utiču brojni, tesno povezani faktori.

Od sva tri aspekta životne okoline zemljište je svakako najsloženije, kako po sastavu i fizičko-hemijskim karakteristikama, tako i zbog uzajamnog delovanja sa zagađivačima. Dosadašnja istraživanja većim delom su usmerena ka uticaju zagađivača na vodu i vazduh, a manjim delom na zemljište. Ovaj rad je doprinos razjašnjenju problema zagađenja zemljišta naftnim derivatima.

\section{Dizel goriva kao potencijalni zagađivači zemljišta}

Dizel goriva su tečna ugljovodonična jedinjenja koja se dobijaju iz nafte, po frakcionom sastavu to su gasna ulja koja sadrže do 500 različitih jedinjenja. Prema uslovima eksploatacije dizel goriva se dele na vrlo laka (D1), laka (D2), srednja (D3) i specijalna (DS).

U dizel goriva spadaju frakcije nafte, od petroleja do lakih ulja. Prema hemijskom sastavu to su složene smeše velikog broja različitih ugljovodonika $\mathrm{sa}_{8}$ do $\mathrm{C}_{26}$ atoma u molekulu, kao organskih jedinjenja sumpora, azota i kiseonika. Osnovu dizel goriva čine molekuli sa $\mathrm{C}_{12}$ do $\mathrm{C}_{20}$ atoma, koji najvećim delom isparavaju u granicama od $170^{\circ} \mathrm{C}$ do $350^{\circ} \mathrm{C}$. Slično ostalim tečnim naftnim proizvodima, u dizel gorivima su prisutne sledeće grupe ugljovodonika:

- alkani i izo-alkani (parafini), od $\mathrm{C}_{10} \mathrm{H}_{22}$ do $\mathrm{C}_{26} \mathrm{H}_{54}$ (oko 41\%);

- monociklični, diciklični i triciklični cikloalkani (petočlani, šestočlani i mešoviti nafteni), koji se kreću u granicama $\mathrm{C}_{10} \mathrm{H}_{20}$ do $\mathrm{C}_{26} \mathrm{H}_{52}(36 \%)$;

- monoaromatski ugljovodonici, diaromatski ugljovodonici (od $\mathrm{C}_{12} \mathrm{H}_{18}$ do $\mathrm{C}_{24} \mathrm{H}_{42}$ ) i jedinjenja mešanih naftensko-aromatskih struktura $\left(\mathrm{C}_{\mathrm{n}} \mathrm{H}_{2 \mathrm{n}-8}\right)(22,6 \%)$;

- policiklična aromatska jedinjenja $(0,4 \%)$.

Osnovne fizičko-hemijske karakteristike dizel goriva prikazane su u tabeli 1 .

Fizičko-hemijske karakteristike dizel goriva

Tabela 1

\begin{tabular}{|l|c|c|c|c|}
\hline \multirow{2}{*}{ Karakteristike } & \multicolumn{4}{c|}{ Dizel goriva } \\
\cline { 2 - 5 } & D1 & D2 & D3 & D2S \\
\hline Gustina na $15^{\circ} \mathrm{C}, \mathrm{g} / \mathrm{cm}^{3}$ & $0,80-0,84$ & $0,81-0,86$ & $0,83-0,88$ & $0,81-0,86$ \\
\hline Destilacija & & & - & - \\
\hline $\begin{array}{l}\text { - do } 300^{\circ} \mathrm{C} \text {, predestiliše najmanje, vol. \% } \\
- \text { do } 360^{\circ} \mathrm{C}, \text { predestiliše } \\
\text { najmanje, vol. \% }\end{array}$ & 90 & - & 60 & 90 \\
\hline Viskozitet na 20 ${ }^{\circ} \mathrm{C}, \mathrm{mm}^{2} / \mathrm{s}$ & - & 90 & $5,0-25,0$ & $1,8-9,0$ \\
\hline Filtrabilnost, ${ }^{\circ} \mathrm{C}$, zimski/letnji diz., ispod & $1,0-6,5$ & $1,8-9,0$ & - & $-20,-$ \\
\hline Tačka paljenja, ${ }^{\circ} \mathrm{C}$, iznad & $-17,-7$ & $-9,+1$ & 65 & 55 \\
\hline Koks, mas. \%, najviše & 40 & 55 & 0,30 & 0,10 \\
\hline Pepeo, mas. \%, najviše & 0,10 & 0,15 & 0,05 & 0,02 \\
\hline Voda, vol. \%, najviše & 0,01 & 0,02 & 0,25 & 0,10 \\
\hline Sumpor, mas. \%, najviše & 0,05 & 0,10 & 1,5 & 0,2 \\
\hline Cetanski broj, najmanje & 0,5 & 1,0 & 35 & 45 \\
\hline
\end{tabular}


Gustina dizel goriva zavisi od temperature. Dizel goriva su smeše nekoliko stotina jedinjenja čija je gustina različita, dok se gustina same smeše kreće od 0,8 do $0,88 \mathrm{~g} / \mathrm{cm}^{3}$. Dizel gorivo ima odgovarajući viskozitet koji je neophodan za optimalno raspršivanje, rad pumpe visokog pritiska motora i proticanje pri niskim temperaturama. Filtrabilnost dizel goriva i tačka stinjavanja su temperature pri kojima dolazi do prekida proticanja goriva usled kristalizacije parafina. Tačka paljenja je temperatura goriva pri kojoj se iznad površine goriva formiraju gasovi koji se pale otvorenim plamenom. U dizel gorivu sumpor se nalazi u nekim organskim jedinjenjima. Njegovo prisustvo je nepoželjno zbog zagađenja životne sredine, korozije motora i smanjenja toplotne moći goriva. Cetanski broj predstavlja sklonost dizel goriva ka samopaljenju i zavisi od hemijskog sastava goriva. Sa porastom cetanskog broja raste i sklonost ka samoopaljenju.

Razlike između dizel goriva za vozila putnog saobraćaja, ulja za loženje i goriva za brodske dizel motore prikazane su u tabeli 2 [2].

\section{Karakteristike zemljišta}

Zemljište je površinski sloj Zemljine kore, nastao kao rezultat zajedničkog uticaja na geološki supstrat elemenata klime, živih i mrtvih organizama, vremena i lokalnog reljefa [3]. To je trofazni i polidisperzni sistem, čiju tvrdu fazu čine mineralne i organske čestice $(40-60 \%$ ukupne zapremine zemljišta), sadrži tečnu vodu sa rastvorenim gasovima i sastojcima tvrde faze, dok je ostatak obuhvaćen porama čiji udeo varira od 20 do $80 \%$. Najvažnije osobine zemljišta su morfologija, hemijski i mineralni sastav, fizičke, hemijske i biološke osobine, kao i vodni, vazdušni, toplotni i hranljivi režimi. Trofazni sistem zemljišta prikazan je na slici 1 .

Najvažnije fizičke osobine zemljišta su mehanički sastav, dubina, specifična masa, zapreminska masa (zbijenost), specifična površina i poroznost (šupljikavost).

Mehaničkim sastavom objašnjava se prisustvo mehaničkih elemenata, odvojenih komada stena i minerala, kao i čestica organskih materija, obrazovanih pro-

Fizičko-hemijske karakteristike dizel goriva D2 za vozila putnog saobraćaja, ulja za loženje i goriva za brodske dizel agregate

\begin{tabular}{|l|c|c|c|}
\hline \multicolumn{1}{|c|}{ Karakteristike } & Dizel goriva (D2) & Ulja za loženje & Brodski dizel \\
\hline Gustina na $15^{\circ} \mathrm{C}, \mathrm{g} / \mathrm{cm}^{3}$ & $0,83-0,86$ & $0,81-0,90$ & $0,82-0,92$ \\
\hline Destilacija, ${ }^{\circ} \mathrm{C}$ & $160-390$ & $160-400$ & $170-420$ \\
\hline Viskozitet na $40^{\circ} \mathrm{C}, \mathrm{mm}^{2} / \mathrm{s}$ & $2,0-4,5$ & $2,0-7,4$ & $1,5-7,4$ \\
\hline Tačka paljenja, ${ }^{\circ} \mathrm{C}$, iznad & 56 & 56 & 60 \\
\hline Tačka stinjavanja, ${ }^{\circ} \mathrm{C}$, ispod & -5 & 0 & -6 \\
\hline Sumpor, mas. \%, najviše & $0,005-0,05^{*}$ & 0,2 & $1,5-2,0$ \\
\hline
\end{tabular}

* Podaci su preuzeti iz API standarda i standarda Evropske zajednice, čiji su zahtevi za neke fizičko-hemijske karakteristike stroži od naših. 


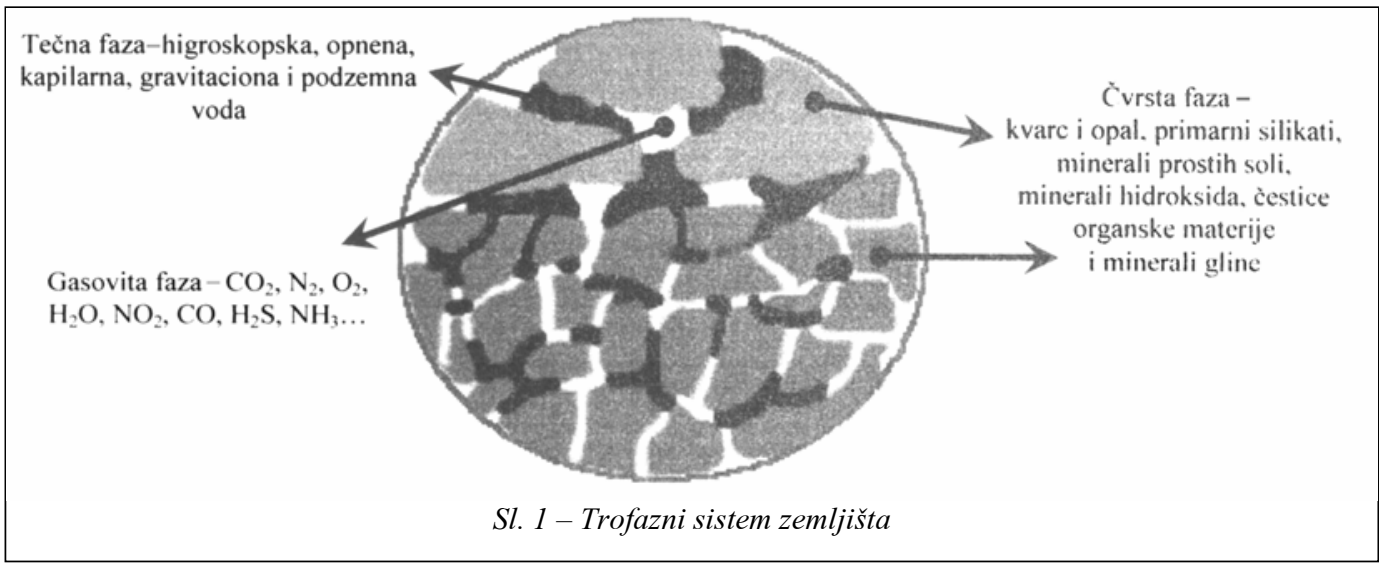

cesima transformacije stena, minerala i organskih ostataka. Prema međunarodnoj klasifikaciji mehanički elementi su razvrstani u šest grupa: kamenje, šljunak, pesak, prah, glina i koloidi.

Dubina zemljišta je rastojanje od površine do dna zemljišnog profila, a varira od 2 do $3 \mathrm{~cm}$ do 2 do $3 \mathrm{~m}$. Po dubini, zemljište se deli na pet klasa: veoma plitko $(<15 \mathrm{~cm})$, plitko $(15-30 \mathrm{~cm})$, srednje duboko (30-60 cm), duboko (60-100 $\mathrm{cm})$ i veoma duboko $(>100 \mathrm{~cm})$.

Specifična masa predstavlja masu jedinične zapremine zemljišta osušenog na $105^{\circ} \mathrm{C}$, bez pora. Specifična masa zemljišta siromašnog humusom varira od 2,5 do $2,7 \mathrm{~g} / \mathrm{cm}^{3}$, dok se kod humusom bogatih zemljišta ona kreće od 2,3 do $2,4 \mathrm{~g} / \mathrm{cm}^{3}$.

Zapreminska masa zemljišta je masa jedinične zapremine zemljišta osušenog na $105^{\circ} \mathrm{C}$, sa porama. Ovde se uzima u obzir tvrda i gasovita faza zemljišta. Vrednosti zapreminske mase kreću se od $0,2 \mathrm{~g} / \mathrm{cm}^{3} \mathrm{u}$ nekim humusom bogatim zemljištima do $2 \mathrm{~g} / \mathrm{cm}^{3} \mathrm{u}$ jako zbijenim glinušama.

Specifična površina je zbir površina svih čestica u jedinici mase zemljišta. U zemljištu bogatom humusom i minerali- ma gline specifična površina je izuzetno velika. Na primer, specifična površina gline, sastavljene pretežno od minerala smektita i vermikulita, varira od 600 do $800 \mathrm{~m}^{2} / \mathrm{g}$.

Poroznost zemljišta je zbir zapremina svih pora u zemljištu, izražen u procentima u odnosu na ukupnu zapreminu. Veličina pora, prema širini, kreće se od dela mikrona $(<1 \mathrm{~nm})$ do preko $10 \mathrm{~cm}$, a prema dužini od dela milimetra do preko $100 \mathrm{~cm}$. Najvažnije hemijske osobine zemljišta su hemisorpcija, fizičko-hemijska adsorpcija jona, biološka, mehanička i fizička sorpcija materija, kiselost i alkalnost.

Pod hemisorpcijom se podrazumeva obrazovanje teško rastvorljivih jedinjenja koja se talože iz zemljišnog rastvora i ulaze u sastav tvrde faze zemljišta. Fizičko-hemijska adsorpcija jona je sposobnost zemljišta da na površinama koloidnih disperzija adsorbuje i razmenjuje ranije adsorbovane jone sa ekvivalentnom količinom jona iz zemljišnog rastvora. Biljke uzimaju materije iz zemljišta i prizemne atmosfere što se naziva biološkom sorpcijom. Mehanička sorpcija je sposobnost zemljišta da u svojim porama 
mehanički zadržava koloidne i krupnije disperzije, a fizička sorpcija (adsorpcija) - privlačenje i zadržavanje na površinama čestica zemljišta molekula gasova, vode, rastvorenih materija, koloida i mikroorganizama pod uticajem međumolekulskih adsorpcionih sila. Isušene čestice zemljišta najbolje adsorbuju vodenu paru, obrazujući tanku opnu higroskopske vode, a od tečnosti molekule organskih materija. Organske molekule najbolje adsorbuju minerali gline, pre svih smektit. Glinom bogata zemljišta odlično adsorbuju i gasove $\left(\mathrm{NH}_{3}, \mathrm{HCN}, \mathrm{COCl}_{2} \ldots\right)$.

Kiselost zemljišta uslovljena je prisustvom vodonikovih jona koji se obrazuju disocijacijom različitih kiselina i hidrolitičkih kiselih soli (npr. $\mathrm{H}_{2} \mathrm{CO}_{3}$, $\mathrm{AlCl}_{3}, \mathrm{FeSO}_{4}$ ). Pod alkalnošću zemljišta podrazumeva se prevladavanje slobodnih hidroksilnih jona u odnosu na vodonikove jone. Povećana alkalnost uslovljena je pojačanim prisustvom hidrolitičkih alkalnih soli $\left(\mathrm{CaCO}_{3}\right.$, karbonati i silikati alkalnih metala).

Kada je reč o sastavu minerala, većina vrsta minerala prisutnih u zemljištu svrstava se u neku od sledećih zbirnih grupa: primarni silikati, kvarc i opal, minerali gline, minerali prostih soli i minerali hidroksida. U zemljištu su najzastupljeniji kvarc i opal i minerali gline. Kvarc i opal zastupljeni su preko $90 \% \mathrm{u}$ pesku i u malim količinama u gotovo svim vrstama gline. Minerali gline su sitnodisperzni sekundarni hidratisani alumo, alumoferimagnezijski i magnezijski silikati sa promenljivim sadržajem glavnih sastojaka ( $\mathrm{Si}, \mathrm{Al}, \mathrm{Fe}, \mathrm{Mg}, \mathrm{H}_{2} \mathrm{O}$ ) i prisustvom mnogih drugih elemenata u malim količinama $(\mathrm{Mn}, \mathrm{Ti}, \mathrm{Ni}, \mathrm{Cr}, \mathrm{Co}, \mathrm{Cu}$, $\mathrm{Zn}, \mathrm{Pb}, \mathrm{B}, \mathrm{P}, \mathrm{S}, \mathrm{Cl}$ i F).

\section{Kretanje dizel goriva izlivenog u zemljište}

Dizel gorivo može se naći u zemljištu, što je posledica akcidentnog izlivanja.

U površinskim slojevima tla gorivo se može naći raspodeljeno između tečne, čvrste i gasovite faze zemljišta, odnosno, adsorbovano na česticama, rastvoreno $u$ vodi, u gasovitom stanju ili kao slobodna tečna faza. Slobodna tečna faza obrazuje se samo pri većim koncentracijama izlivanja. Od raspodele po fazama zavisi kretanje (prodiranje) goriva kroz površinske slojeve [4-6].

Dizel gorivo može prodirati kroz zemljište u horizontalnom i vertikalnom pravcu. Horizontalno kretanje, ili bočno rasprostiranje, značajno je kod tla zasićenih vodom, ili kada gorivo stigne do gornje granice nivoa podzemnih voda. Sa horizontalnim kretanjem, ukoliko je ono ograničeno na površinske slojeve, povećava se kontaminirana površina, ali je olakšana fotodegradacija i uklanjanje lakših ugljovodonika isparavanjem. Vertikalno kretanje kroz profil zemljišta, posredstvom gravitacije, u većini slučajeva akcidentnih izlivanja predstavlja dominantan proces. Brzina vertikalnog prostiranja zavisi od prirode i strukture zemljišta, vrste i količine naftnog zagađivača, klimatskih faktora i gustine vegetacionog pokrivača.

Pored horizontalnog i vertikalnog prostiranja, dizel gorivo u zemljištu može se kretati i pod uticajem podzemnih voda, kao slobodna tečna faza formirana iznad podzemnih voda. Takođe, važno je i kretanje gasovite faze koja u odnosu na tečnu brže prolazi između strukturnih agregata zemljišta i na taj način preostalu ugljovo- 
doničnu masu čini gušćom i viskoznijom, a samim tim i manje pokretnom.

Prostiranje izlivenog goriva kroz zemljišni profil prikazano je na slici 2 .

\section{Remedijacija zagađenog zemljišta}

Remedijacijom zagađenog zemljišta obuhvaćeni su postupci čišćenja radi sanacije posledica zagađenja. Remedijaciju je moguće sprovesti na samom mestu zagađenja ili premeštanjem zagađenog zemljišta na druge lokacije. Čišćenje zemljišta na mestu zagađenja dozvoljeno je samo pod uslovom da nema opasnosti po životnu sredinu, odnosno, da u blizini nema ljudskih naselja, postrojenja za snabdevanje vodom ili osetljivih životnih zajednica, kao što su močvare, jezera, reke i sl. [7]. Izbor mesta i načina remedijacije, kao i optimalnog vremena realizacije, zavisi od mnogih faktora (koncentracije izlivenog goriva, vrsta izlivene materije, vremena tokom kojeg je zemljište izloženo zagađenju, distribucije zagađivača $u$ zemljišnom profilu, dubine podzemnih voda, stepena ugrožavanja životne sredine [1].

Navodimo najvažnije tehnike remedijacije:
Vakuum-ekstrakcija pogodna je za uklanjanje isparljivih jedinjenja iz zemljišta ili iz slobodne tečne faze formirane iznad podzemnih voda. Zasnovana je na stvaranju vakuuma u posebno iskopanim bunarima, u koje se iz okolnog zemljišta izvlači vazduh. Protok vazduha podstiče isparavanje lakše isparljivih jedinjenja $i$, na taj način, uz pomoć vakuuma, vrši se uklanjanje zagađivača iz zemljišta. Tehnika vakuum-ekstrakcije najefikasnija je na zemljištima zagađenim benzinskim frakcijama.

Ispiranje zagađenog zemljišta zasniva se na ispiranju vodom sa deterdžentima ili pogodnim rastvaračima (metanol, heksan i sl.). Ispiranje zemljišta moguće je izvršiti na mestu zagađenja ili skidanjem zagađenog sloja i njegovim propuštanjem kroz postrojenja za ekstrakciju. Ovu tehniku treba sprovoditi oprezno, naročito na mestu zagađenja, jer u tom slučaju postoji mogućnost ugrožavanja podzemnih voda ili izvora pitke vode.

Biodegradacija mikroorganizmima koji potiču sa mesta zagadenja. Mikroorganizmi koji potiču sa mesta zagađenja mogu da razgrade naftne zagađivače koji

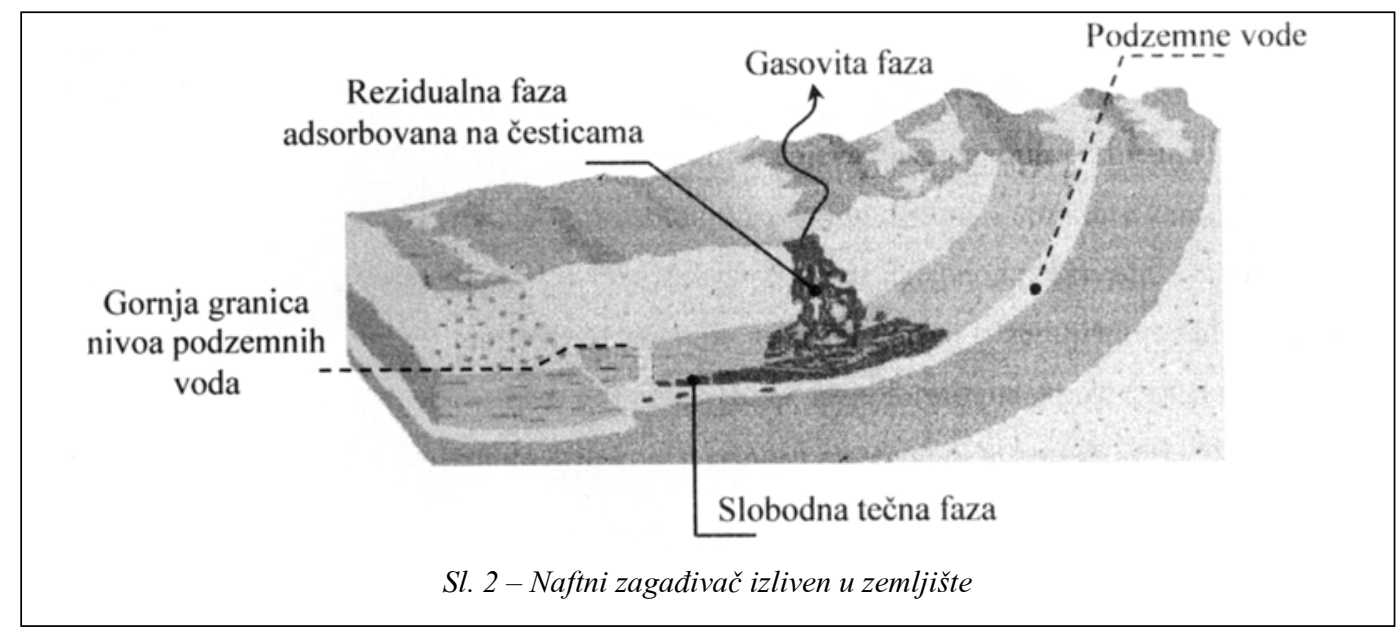


su u nezasićenoj zoni adsorbovani na česticama zemljišta (rezidualna faza). Aktivnost mikroorganizama može se pojačati uvođenjem svežeg vazduha i odgovarajuće prihrane, ali brizina strujanja vazduha ne sme biti velika. Ova metoda je veoma uspešna pri izlivanju srednjih destilata nafte (petrolejske i dizelske frakcije).

Obrada zemlje. Na mestu zagađenja, ukoliko je zagađenje manjeg obima, može se izvršiti i specijalna obrada zemljišta, odnosno iskopavanje zagađenog zemljišta, koje se razbacuje preko nepropusne plastične folije u obliku tankog sloja. Zagađivači se uklanjaju isparavanjem, biodegradacijom i fotodegradacijom.

Fiksacija zemljišta. Zagađeno zemljište može se odvojiti od tla i pomešati sa cementnim jedinjenjima i stabilizatorima. Cementna jedinjenja vezuju se sa zagađivačem, a stabilizatori sprečavaju odvajanje rastvorljivih jedinjenja od zacementirane mase. Ovako fiksirano zemljište vraća se na mesto gde je iskopano.

Termička obrada. Izlaganjem zagađenog zemljišta povišenim temperaturama moguće je iz njega odstraniti zagađivače poreklom iz nafte. Oni se uklanjaju isparavanjem, povećanjem njihove pokretljivosti i potpunim spaljivanjem. Ova tehnika ne sme se sprovoditi ukoliko nisu preduzete neophodne mere zaštite vazduha od gasova koji se oslobađaju tokom sagorevanja i isparavanja.

\section{Opis eksperimenta}

$\mathrm{U}$ radu je ispitivana promena koncentracije izlivenog dizel goriva $u$ vremenu, u površinskim slojevima peska.
Plastične cevi dimenzija $30 \times 15 \mathrm{~cm}$ napunjene su peskom zapreminske gustine $1,65 \mathrm{~g} / \mathrm{cm}^{3}$. Za eksperiment je odabran dunavski refulisan pesak, prikupljen sa desne obale Dunava, $7 \mathrm{~km}$ uzvodno od Zemuna. Na površinu peska izliveno je dizel gorivo D-2 u koncentraciji $10 \mathrm{l} / \mathrm{m}^{2}$ (prosečna koncentracija akcidentnih izlivanja). Kolone sa zagađenom zemljom držane su šest nedelja napolju pod nadstrešnicom, u realnim uslovima, pri promenljivoj temperaturi i vlažnosti vazduha. Površina zagađenog zemljišta delimično je bila izložena vetru i sunčevoj svetlosti, ali ne i padavinama.

Meteorološki uslovi eksperimenta prikazani su u tabeli 3 .

Uslovi eksperimenta

Tabela 3

\begin{tabular}{|c|c|c|c|c|}
\hline \multirow{2}{*}{$\begin{array}{c}\text { Period } \\
\text { (dani) }\end{array}$} & \multicolumn{2}{|c|}{ Temperatura, ${ }^{\circ} \mathrm{C}$} & \multicolumn{2}{|c|}{ Relativna vlažnost, \% } \\
\hline $0-11$ & 4,18 & $14 /-3$ & 64 & $95 / 30$ \\
\hline $11-41$ & 13 & $23 / 2$ & 56 & $97 / 20$ \\
\hline
\end{tabular}

Uzorci zagađenog zemljišta uzimani su neposredno nakon izlivanja, a zatim 11. i 41. dana iz četiri površinska sloja: 0 $5 \mathrm{~cm}, 5-10 \mathrm{~cm}, 10-15 \mathrm{~cm}$ i $15-30 \mathrm{~cm}$. Nakon vađenja iz kolona svaki sloj je dobro promešan, upakovan u plastične vrećice i do ekstrakcije držan na $-5^{\circ} \mathrm{C}$. Napravljeno je onoliko kolona koliko je puta uziman uzorak, odnosno, nakon uzimanja uzoraka kolona je ispražnjena, a za naredno uzimanje pripremljena je druga kolona, po svemu istovetna prethodnoj.

Uzorci zagađenog zemljišta esktrahovani su najkasnije sedam dana nakon uzimanja. Ekstrakcija je sprovedena prema modifikovanoj proceduri definisanoj standardom ISO/DIS 16703. Oko $4 \mathrm{~g}$ zemlje ekstrahovano je na mehaničkoj tresilici acetonom analitičke čistoće, u količini 
od $3 \mathrm{ml}$ acetona po gramu zagađene zemlje. Ekstrakcija je trajala $3 \times 15$ minuta. Nakon toga, na uređaju za centrifugiranje odvojen je rastvor od zemlje, a onda je na vakuum-evaporatoru, uz pomoć vodene pumpe, uklonjen aceton. Dobijeni ekstrakt sušen je na sobnoj temperaturi 4 sata.

Masa ekstrakta izmerena je i izražena u miligramima, na prvu decimalu. Izmerena masa ekstrahovanog dizel goriva preračunata je u koncentraciju zagađenja, odnosno koncentraciju izlivenog goriva (mg goriva/kg zemlje).

Dizel gorivo, ekstrahovano iz površinskih slojeva peska, analizirano je metodom gasne hromatografije na uređaju Varian 3400 sa plameno-jonizujućim detektorom. Rezultat analize je distribucija normalnih alkana ili raspodela relativnih koncentracija n-alkana u nizu od dekana do pentakozana.

\section{Rezultati i diskusija}

Rezultati eksperimenta prikazani su u tabeli 4.

Tabela 4

Koncentracija izlivenog dizel goriva po slojevima zemljišta

\begin{tabular}{|c|c|c|c|}
\hline Zemljište & \multicolumn{3}{|c|}{ Pesak } \\
\hline \multirow{2}{*}{ Sloj } & \multicolumn{2}{|c|}{$\begin{array}{c}\text { Koncentracija ekstrahovanog dizel } \\
\text { goriva, mg/kg }\end{array}$} \\
\cline { 2 - 4 } & $\begin{array}{c}\text { Neposredno } \\
\text { nakon izlivanja }\end{array}$ & 11. dan & 41. dan \\
\hline $0-5 \mathrm{~cm}$ & 89482 & 38606 & 27276 \\
\hline $5-10 \mathrm{~cm}$ & 1648 & 31893 & 24219 \\
\hline $10-15 \mathrm{~cm}$ & - & 12063 & 19480 \\
\hline $15-30 \mathrm{~cm}$ & - & 310 & 3046 \\
\hline
\end{tabular}

U prvih šest nedelja nakon izlivanja koncentracija izlivenog dizel goriva $u$ površinskom sloju peska neprestano se smanjuje. Znatno smanjenje nastupilo je nakon jedanaest dana (više nego dvostruko). Na kraju ispitivanog perioda kon- centracija izlivenog goriva $\mathrm{u}$ sloju $0-5$ $\mathrm{cm}$ smanjila se više nego trostruko. $\mathrm{U}$ sloju peska dubine 5-10 cm koncentracija izlivenog goriva $u$ prvih jedanaest dana povećala se skoro 20 puta. Do kraja ispitivanog perioda koncentracija u ovom sloju smanjila se za oko $25 \%$ u odnosu na 11. dan.

U donjim slojevima peska nije utvrđeno prisustvo goriva neposredno nakon izlivanja. U sloju 10 do $15 \mathrm{~cm}$ koncentracija izlivenog goriva povećava se u celom ispitivanom periodu, ali je znatno povećanje nastupilo nakon jedanaest dana. Porast koncentracije u sloju 15 do 30 $\mathrm{cm}$ utvrđen je u periodu od 11. do 41. dana (oko 10 puta).

Koncentracija izlivenog goriva $u$ površinskom sloju peska smanjuje se usled isparavanja lako isparljivih jedinjenja i migracije goriva $u$ donje slojeve. Promena koncentracije u sloju $5 \mathrm{do} 10 \mathrm{~cm}$ uslovljena je prodorom goriva u prvih jedanaest dana, odnosno, isparavanjem $\mathrm{i}$ migracijom $u$ dublje slojeve $u$ periodu od 11. do 41. dana. Prodor goriva je dominantan proces $\mathrm{u}$ donjim slojevima peska $\mathrm{u}$ celom ispitivanom periodu. Znatan prodor u najdubljem sloju peska utvrđen je nakon 11. dana.

$\mathrm{Na}$ osnovu podataka o koncentracijama izlivenog goriva (tabela 4) moguće je izvesti zaključke o remedijaciji površinskih slojeva peska:

a) neposredno nakon izlivanja do 5 $\mathrm{cm}$. U ovom sloju, neposredno nakon izlivanja, zadržana je gotovo celokupna količina dizel goriva. Ukoliko izlivanjem nije zahvaćena veća površina, sloj se može skinuti i tretirati tehnikama ispiranja ili obradom zemlje; 
b) jedanaestog dana do $15 \mathrm{~cm}$. Do 11. dana, u sloju 0 do $5 \mathrm{~cm}$ zadržalo se $46 \%$ ukupne količine izlivenog goriva, a $\mathrm{u}$ oba gornja sloja, do dubine $10 \mathrm{~cm}$, ukupno $84 \%$. Ostatak goriva (16\%) zadržan je u sloju 10 do $15 \mathrm{~cm}$. U slučaju skidanja zemlje radi remedijacije, masa uklonjene zemlje uvećala bi se trostruko $\mathrm{u}$ odnosu na vreme neposredno nakon izlivanja. Remedijacija se može sprovesti na mestu izlivanja, tehnikom biodegradacije;

c) četrdesetprvog dana do $30 \mathrm{~cm}$. U gornja dva sloja peska zadržano je $2 / 3$ goriva, a na dubini do $15 \mathrm{~cm}$ ukupno $89 \%$. Znatna količina (11\%) nalazi se u najdubljem sloju (15 do $30 \mathrm{~cm})$. S obzirom na to da je izliveno gorivo još uvek u nezasićenoj zoni (rezidualna faza adsorbovana na česticama) preporučena tehnika remedijacije bila bi biodegradacija na mestu izlivanja.

Distribucija relativnih koncentracija n-alkana sa vremenom nakon izlivanja prikazana je na slici 3 .
Distribucija n-alkana menja se sa vremenom nakon izlivanja u površinskom sloju peska. U celom ispitivanom periodu smanjuju se relativne koncentracije n-alkana u nizu od dekana do tridekana (C10-C13). Istovremeno, povećavaju se relativne koncentracije jedinjenja $\mathrm{u}$ nizu od pentadekana do pentakozana. Relativne koncentracije $\mathrm{C} 10-\mathrm{C} 13$ znatno su se smanjile u prvih jedanaest dana nakon izlivanja. Povećanje relativnih koncentracija normalnih alkana $\mathrm{u}$ nizu od kozana do pentakozana (C20-C25) utvrđeno je u periodu od 11. do 41. dana.

Promena relativnih koncentracija undekana i dodekana tokom vremena nakon izlivanja prikazana je na slici 4 .

Relativna koncentracija undekana znatnije se smanjuje sa vremenom. Veća promena koncentracije kod oba jedinjenja, u odnosu na čist dizel, nastupila je već nakon jedanaest dana. Od 11. do 41. dana relativna koncentracija undekana smanjila se dvostruko, a dodekana mnogo manje (od 9,73\% do 7,26\%).

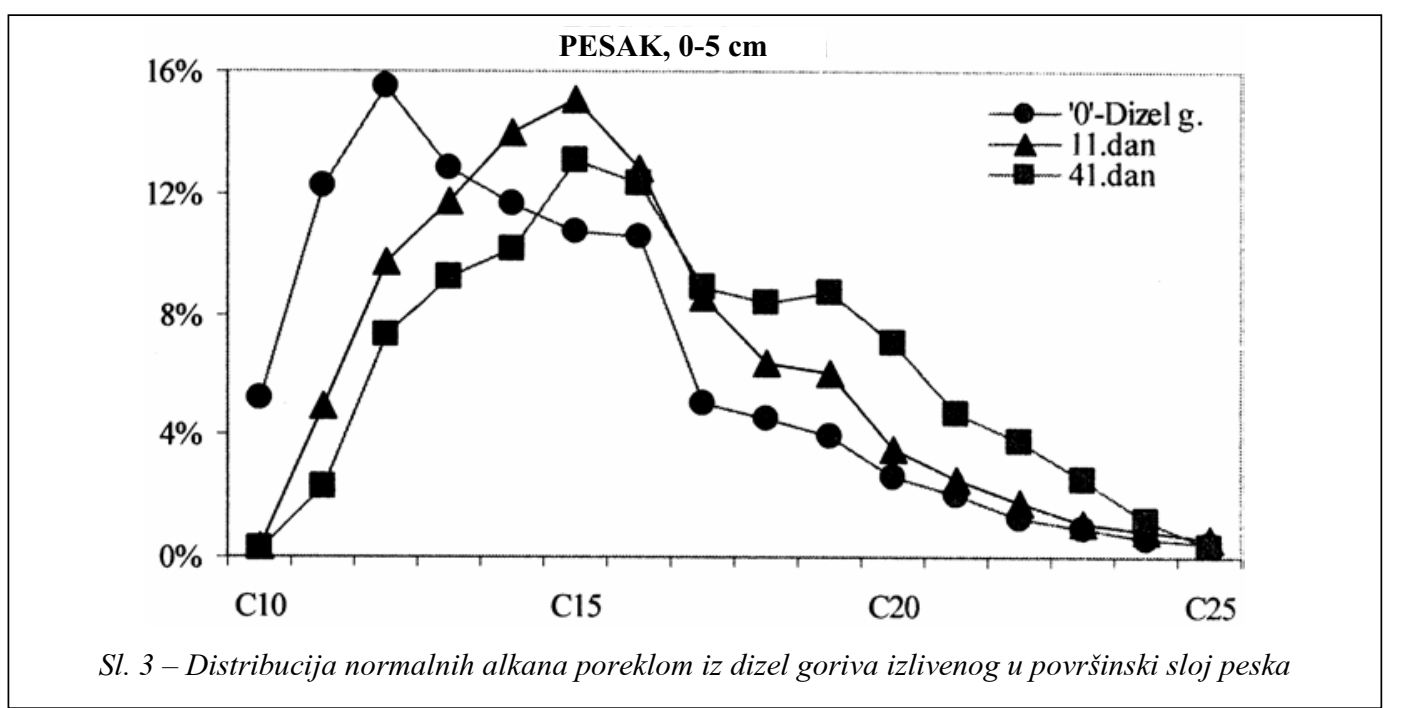




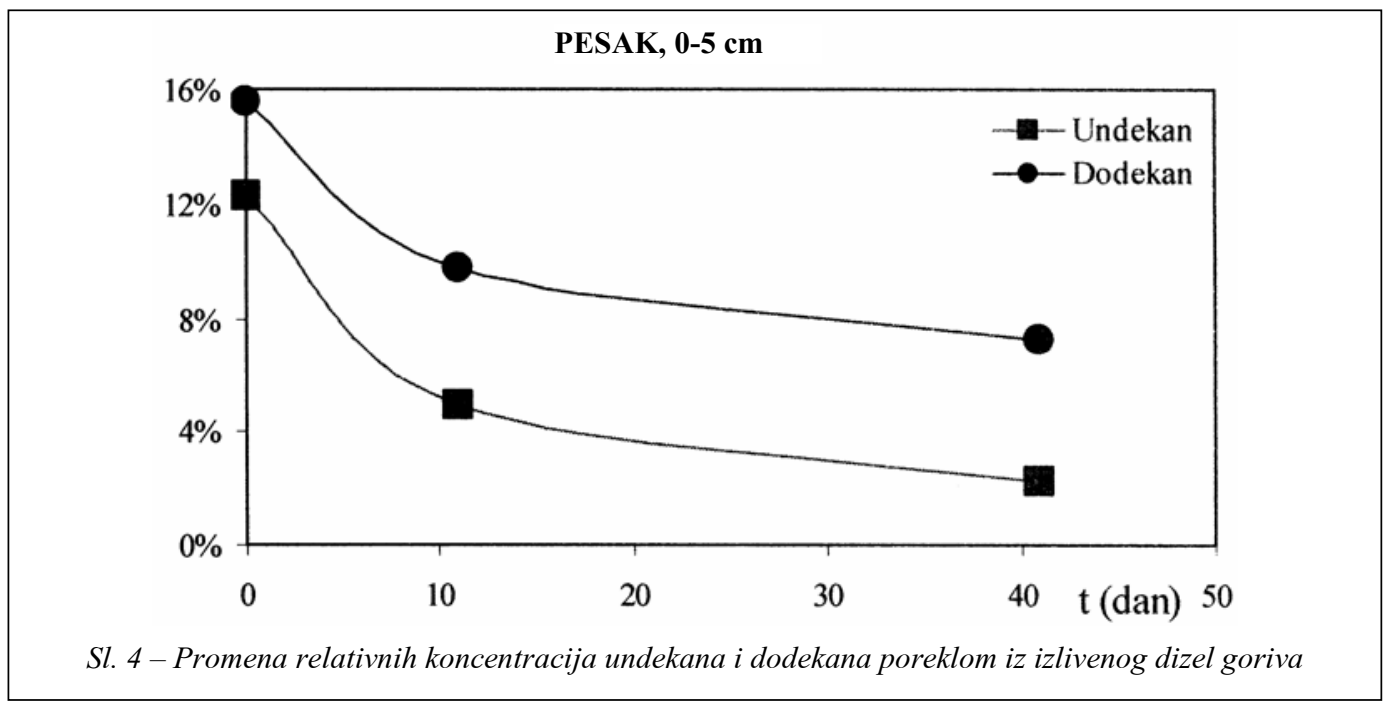

\section{Zaključak}

$\mathrm{Na}$ osnovu eksperimentalnih rezultata prikazanih u ovom radu moguće je zaključiti da je u prvih šest nedelja nakon izlivanja dizel goriva na površinu zemljišta sastava peska, veći deo goriva zadržan u sloju dubine do $30 \mathrm{~cm}$.

Distribucija normalnih alkana zavisi od vremena proteklog nakon izlivanja i može se upotrebiti kao svojevrstan ,otisak prsta“ izlivenog goriva (fingerprint), što je od velikog značaja u procesima praćenja stanja u životnoj sredini i donošenja odluka o sanaciji zagađenog zemljišta.

Relativne koncentracije pojedinih n-alkana mogu poslužiti u procenama vremena izlivanja dizel goriva.
Literatura:

[1] Guidelines for Assessment and Source Removal of Petroleum Contaminated Soil, Florida Department of Environmental Protection - Bureau of Petroleum Storage Systems, May 1998.

[2] CONCAWE, product dossier no.95/107, Brussels, September 1996.

[3] Živković, M. D.; Đorđević, A. R.: Pedologija, Poljoprivredni fakultet, Beograd, 2003.

[4] EPA: Behaviour of Hydrocarbons in the Subsurface, In How to Effectively Recover Free Product At Leaking Underground Storage Tank Sites: A Guide for State Regulators, EPA 510-R-96-001, 1996.

[5] EERC: Boshof, G.; Kalin, R. M.: Non-Aqueous Phase Liquid Behaviour, Environmental Engineering Research Centre, The Queen's University of Belfast, 2001.

URL: http://www.qub.ac.uk

[6] EPA: Monitored Natural Attenuation, chapter IX, 2004. URL: http://www.epa.gov/swerust.1/pubs/tum ch9.pdf

[7] Vermont State Agency of Natural Resources: Agency Guidelines for Petroleum Contaminated Soil and Debris, Department of Environmental Conservation, Waste Management Division, Vermont, 1996. 